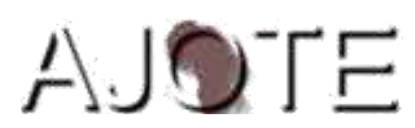

African Journal of Teacher Education

ISSN 1916-7822. A Journal of Spread Corporation

Volume 9. No.2 $2020 \quad$ Pages 23-42

\title{
Impact of Flipped Classroom on Mathematics Learning Outcome of Senior Secondary School Students in Lagos, Nigeria
}

\author{
Semiu Olawale Makinde \\ Al-Hikmah University, Ilorin \\ Nigeria.
}

\begin{abstract}
This study examined the impact of the flipped classroom on the learning outcome of secondary school students in mathematics in Lagos, Nigeria. It examined the impact of a flipped classroom package $(F C P)$ on post-test performance $(P P)$ and retention performance $(R P)$ of students in Mathematics; it also sought to determine the influence of gender on PP and RP of students towards learning mathematics in the flipped classroom $(F C)$. This is in response to the search for means to reverse the poor performance of students in mathematics O'level West African Secondary School Certificate Examinations. The flipped classroom, an innovative teaching technique, was introduced as a possible corrective that could produce effective student learning engagement and performance. A Quasi-experimental design was adopted and 275 Senior secondary school (SSS) 2 Students, 147experimental and 128 as control (conventional) intact classes, constituted the purposive sampled population for the study. Three research instruments: Flipped Classroom Package, Lesson Note and Performance Test were validated by expects and used for the study. The instruments were also checked for reliability; and the inter-rater reliability coefficient of a developed FC package was 0.79; lesson note, 0.83; and test instrument 0.85. Four hypotheses were raised and tested after 6 weeks of the experiment. The results of the findings indicated that the flipped classroom encourages good performance in mathematics and should thus be encouraged in schools for being a student centered learning approach. The study concludes among others that teachers should be encouraged to attend seminars and workshops on the use of the approach for effective performance of the learners.
\end{abstract}

Keywords: Flipped classroom, performance, retention, learning outcome, Information Communication Technology (ICT) 


\section{Introduction}

Adequate and qualitative education can only be achieved through effective teaching and learning. Employing innovative technology in imparting and acquiring knowledge in educational institutions can facilitate this outcome. Nigeria, as a developing country, aims to achieve quality education and its Nigerian National Policy on Education (FRN, 2014) stipulates that education should sustain its citizens and society. One critical means deployed for this purpose is ICT. Students find that Information Communication Technology (ICT) facilitates their access to subject information on the Internet (U. S. Department of Education, 2004). Yusuf (2006) describes ICT as any communication devices or applications like cell phones, television, radio, computer, social networking websites, and satellite systems, among others that are developed as tools for and in support of effective educational delivery.

Among the teaching strategies developed in the field of education to facilitate more effective teaching and learning with the incorporation of latest technology is the flipped classroom. The-flipped classroom refers to a form of blended learning platform where students learn new content online by watching video lectures usually at home, and in reverse, what used to be homework (assigned tasks) is done in class in the presence of teachers. Teachers are thereby able to offer more one on one personalized guidance and interaction with learners, instead of lecturing (Nwosisi, Ferreira, Rosenberg and Walsh, 2016). The FC is also known as the backwards classroom, reverse teaching, and the Thayer Method. Many online digital resources are associated with the flipped classroom, including, Coursera, TED talks, Khan Academy, and YouTube. They provide access to recorded lectures, instructional videos, and at times other interactive elements for teaching and learning. In most cases teachers implementing the FC depend on these resources to provide the lesson content (Bull, Ferster, \& Kjellstrom, 2012).

Teachers searching for content from outside may be helpful for those who lack presentation skills, need an outside perspective to enrich their course, or lack extensive subject knowledge. It has been noted that these large educational video sites are innovations that were not created by established education groups but rather came from outside "to fill the vacuums" that educators had left (Tucker, 2012), leaving the possibilities that as this learning model, as it grows may upturn the role of educators. Makinde (2017) outlines how the flipped classroom works in Lagos, Nigeria; observing that due to inadequate internet connectivity and technical 
knowledge, the teachers usually burn their recorded lessons videos to CD/DVD for students to watch offline at home at their convenience. They would then do the assignment (normal takehome problems) in the class where a teacher gives them guidance in their areas of difficulties and monitors their learning progress. In this situation, more time is available for the teacher to attend to individual learners and all learners were encouraged to learn at their own pace.

Despite the benefit of the flipped classroom, the electricity and other social challenge in Nigeria meant that having an android phone or computer system (Laptop or desktop) is not enough to make the flipped classroom work. Consequently, the flipped classroom method of teaching and learning in Lagos, Nigeria is the simple offline method in which even learners with little knowledge of technology can adapt.

Most available recorded CD/DVD videos commonly used in Nigeria for primary and secondary school students will only assist a few good students because they do not combine feedback or explanation of ambiguous and difficult concepts covered in the curriculum nor do they include an assessment of students' understanding. Teachers modifications based on learners' contributions is not possible. Hence, subjects like Mathematics, English language, and others cannot be adequately understood effectively with merely recorded video clip watching without teacher's guidance (Makinde, 2017). In Nigeria, persistence failure in a major subject like mathematics in final examinations dashed many students hope to gain admission into higher institutions. The data of mathematics students in senior secondary certificate examinations (SSCE) between 2014 - 2019 in Nigeria in figure 1 shows that the learning outcome of students was poor. This demonstrates a requirement for a proactive approach to teaching techniques and methods. 


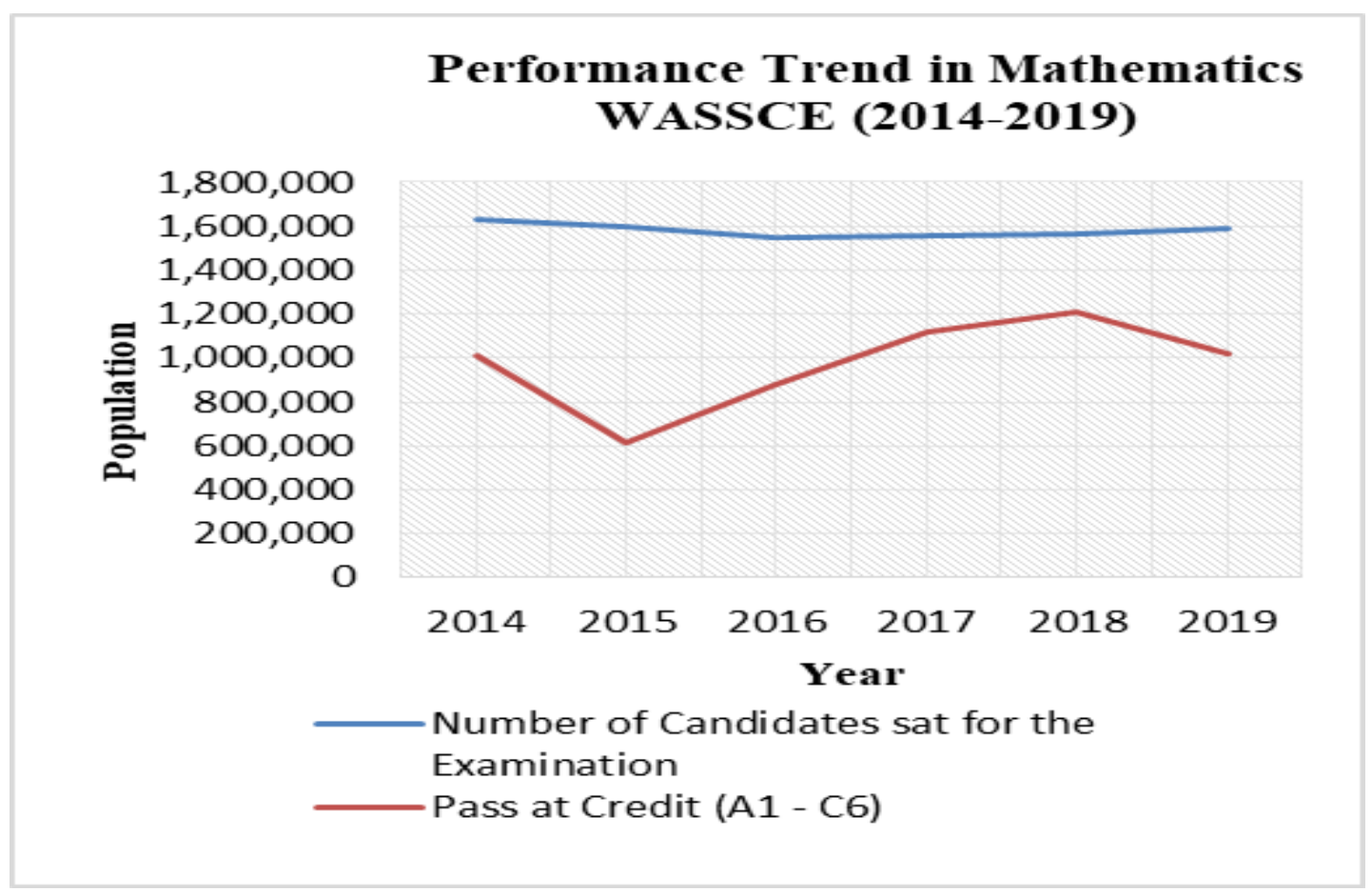

Source: WAEC Office, Lagos, (2019)

Figure1: Performance of Students in SSCE, 2014-2019.

Figure 1 shows that students' performance in Mathematics was above average in 2014 $\{1,011,608(61.97 \%)\}$ but fell drastically in 2015 616,343(38.68\%) and was on average in 2016 (52.97\%). It shows that about 50\% of the students that sat for the West African Senior Secondary Schools Certificate Examinations (WASSCE) do not pass mathematics at the required grade level of at least C6 for admission into tertiary institutions in Nigeria between 2015 to 2016. But students performed better in mathematics between 2017 to 2018 and poorly again in 2019. According to the Chief Examiners Reports for 2014 - 2019 WASSC examinations (WAEC, 2019), the weak and poor student performance in Mathematics was associated with low understanding of the concepts and contents of the major aspect of the mathematics curriculum like trigonometric and geometry. The research quantified that several reasons are responsible for poor mathematics performance of students: poor methods of teaching (Olunloye, 2010); lack of assurance in the subject by the students (Parson, Croft and Harison, 2009), gender pressure (Amelink, 2009) and bad learning environment (Olunloye, 2010). 


\section{Literature Review}

Numerous researches on the flipped classroom consider the FC to be one of the most effective methods of teaching for better engagement and performance of students in almost all subjects because it claims to be a strategy that creates more time for teacher-time with students in the classroom to deal with difficulties (Toppo, 2011; Tucker, 2012). According to Sams and Bergmann, flipped classroom is not about how to use videos in lesson but about how to be best use in-class time with students, an insight calling for classroom teachers at all levels to reevaluate how they teach. The FC approach helps instructors to move away from direct instruction as their primary teaching tool toward a more learner-centred approach (Bergmann \& Sams, 2013). Hence, the flipped classroom allows students who missed normal classes to watch the videos of the lessons at their convenient time at home and still able to contribute effectively during the class interactive session when present with the teacher and the classmates.

Estes, Ingram and Liu's study (2014) of the FC in China proposes a model with three segments to it, viz, a pre-class that calls for students attention to the learning materials on the internet or to off the net activities; segments which involve collaborations and cooperation and include students-teacher and students-students interaction in a classroom setting for active learning; and finally, the post-class segments that are managed via the application of computer technologies to actualize assessment, the use, reproduction or transfer of knowledge through the of flipped classroom approach.

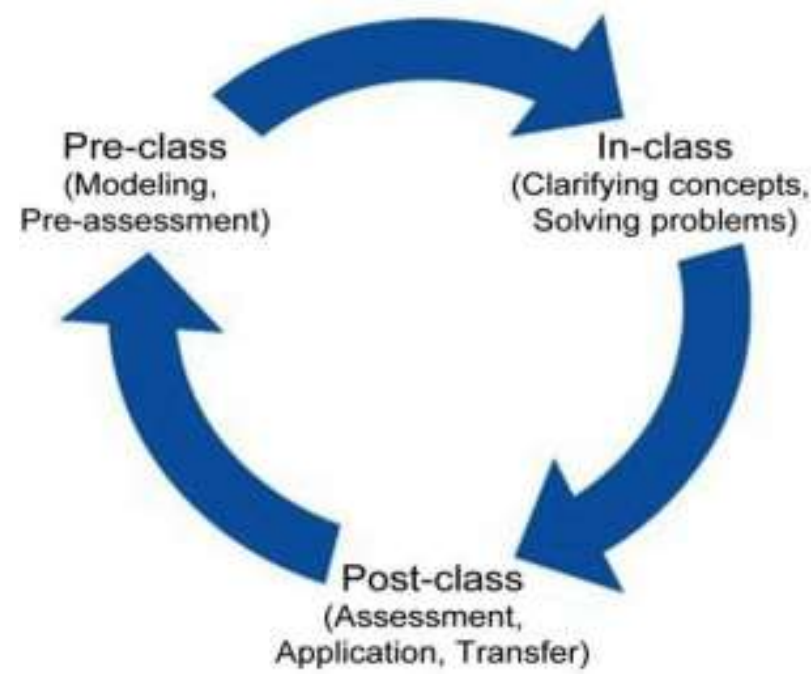

Figure 2. Flipping the classroom sample model 
Source: Estes, Ingram and Liu (2014)

\section{E-Learning and Social Media Strategies for Lagos State Secondary School Students}

In 2012, 2013 and 2014 West African Examinations Council (WAEC) conducted examinations, results indicated that 61, 63 and 70 percent of students, respectively, who sat for the examinations failed. Also, of 1.7 million candidates who register annually for higher institution examination managed by the Joint Admission and Matriculation Board JAMB, only 500,000 of get admission in Nigerian universities. In response to this consistently poor student performance in Senior School Certificate Examinations, SSCE, and Unified Tertiary Matriculation Examination, UTME, the Lagos state government has launched free e-learning or m-learning systems to assist its students in performing better (Okebukola, 2015).

However, this impressive government response and program have difficulties that should be mentioned. In an Okebukola-led research group study on E-Learning and Social media application in education as innovative strategies for promoting the higher achievement of secondary school students in Lagos, a total of 3,441 students and 735 teachers in 320 public and private schools from all the six Lagos State Education Districts were surveyed. The highlights from the findings revealed that though the Lagos State Government has made a notable investment to make Lagos state public schools e-learning ready, only about a quarter of the teachers rated themselves overall to be fully e-learning ready. Two-third of the students expressed their confidence in their ability to use ICT for learning and above 65 percent

frequently use social medial, most especially the Facebook, sometimes for learning but mostly for social interaction. Above three-quarters of teachers and students rated poor internet connectivity as a major problem to e-learning. On all measures of e-learning readiness, private schools outshine their public counterparts in academic performance. Mathematics, Biology Chemistry, English and Commerce are the listed subjects perceived difficult by all teachers and students surveyed (Okebukola, 2015).

Nwosisi, Ferreira, Rosenberg, and Walsh's (2016) study of the college of Westchester, White Plains, New York students concluded with the observation that when at least thirty percent of the lecture content is flipped, the Flipped instruction concept facilitates interaction among students, and between students and their Instructors. Flipped instruction leads to better learning 
results. This concept helps students to effectively learn to acquire skill, knowledge, and to show a good attitude towards learning.

\section{Statement of the Problem}

In recent years, secondary school students in Lagos State have returned abysmal results in public examinations. For the four years from 2016 to 2018 , Osun state was ranked $28^{\text {th }}$ out of 36 states in Nigeria by WAEC (2018). One of the solutions to this problem is to adopt an effective teaching method and the Flipped classroom (FC) instructional method is reported to be among the most effective. It provides the teacher more time to spend with students in class on difficult topics (Toppo, 2011; Tucker, 2012); Students who miss classes for one reason or the other can watch the videos of the lessons at their convenient time at home and still be able to catch up with the class (Bergmann \& Sams, 2012). The method encourages thinking in and out of the classroom (Jacob \& Mathew, 2013) and frees up classroom time for teacher-student interactive learning activities.

The task the current study set itself was, therefore, to contribute to empirically determine the efficacy of FC for teaching and learning mathematics in senior secondary schools in Lagos State and the Nation in general. Going by the findings of recent studies of e-learning platform in Lagos state, internet connectivity and erratic power supply are the major problems of online learning in Lagos state (Okebukola, 2015). The studies also show that private schools were more responsive to the treatment than were the public schools. They also show that flipped classroom can work without internet, the less demand on technology, making it more appropriate for the context and therefore more preferable than other methods of innovative learning. Based on this insight, the current study used offline flipped classroom pedagogy to investigate the impact of learning package "flipped classroom" utilization as a new teaching strategy for mathematics students in the private-owned bridge (Day/Boarding) secondary schools in Lagos, Nigeria. ${ }^{11}$

\section{Research Objectives}

The purpose of this research was to examine the utilization and adequacy of a developed FCP on

\footnotetext{
${ }^{1}$ This type of schools accommodates both the boarding and day students learning together in the same school premises during learning period usually between the hour of $8.00 \mathrm{am}$ and 4.00pm during the week. The boarders usually return to their hostel where they have the opportunity to continue learning via organized tutorials and peer collaboration. The day students, meanwhile, would leave for their homes.
} 
Senior Secondary School (SSS) Students' performance in Mathematics. The objectives of the study are to:

1. Examine the difference(s) between the post-test performance of students taught mathematics with a developed Flipped Classroom (FC) package and those taught with Conventional Classroom (CC) in other to determine its adequacy in mathematics teaching in SSS in Lagos, Nigeria

2. Determine the difference(s) between the retention performance of SSS students taught using a developed FC package and those taught mathematics using the $\mathrm{CC}$ in a mathematics class in Lagos, Nigeria

3. Examine the difference(s) between the post-test performance of male and female students taught mathematics using a developed FCP in SSS in Lagos, Nigeria

4. Determine the difference(s) between the retention performance of male and female students taught mathematics with a developed flipped classroom in SSS in Lagos, Nigeria

\section{Research Hypotheses}

The null hypotheses formulated from the research objectives and tested in this study were as follow:

Ho1: Significant difference does not exist between the post-test performance of students taught mathematics with a developed Flipped Classroom (FC) package and those taught with the Conventional Classroom (CC) in SSS in Lagos, Nigeria

Ho2: There is no significant difference between the retention performance of students taught using a developed FC package and those taught mathematics using the CC in SSS in Lagos, Nigeria

Ho3: Significant difference does not exist between the post-test performance of male and female students taught mathematics using a developed FCP in SSS in Lagos, Nigeria

Ho4: Significant difference does not exist between the retention performance of male and female students taught mathematics with a developed flipped classroom in SSS in Lagos, Nigeria.

\section{Research Method}

The study employed a quasi-experimental design of pre-test and post-test. The learning method (flipped classroom method) was crossed with gender (male and female). The dependent variables AJOTE Vol. 9 No. 2 (2020), 23-42 
were retention and post-test performance while the intervening variables were gender. The population comprises of all Senior Secondary School (SSS) students in Lagos State, while the purposive sample population was all SSS II private bridged school students from an education district in Lagos state, Nigeria. The bridge private secondary school was used for the benefit of positive interactive effect expected between the boarders and day student. This class and school type was purposively used because of their enthusiastic readiness to participate in research studies, including this, and because they comprised of students who could afford the technology that will prepare them for their Senior Secondary Certificate Examinations (SSCE). Also, they had been taught mathematics for over one year at the senior secondary school level in Lagos. Stratified sampling technique was used in grouping the samples along with gender.

The students who participated did so voluntarily after the purpose of the research had been made clear to them and their rights made known to them in their schools. The total sample size was 275 students in SS2 of 146 males and 129 females. For the experimental group, 78 male and 69 female students totaling 147 constituted the experimental group while 68 males and 60 females, a total of 128, formed the control group. Both groups were picked from intact classes of two bridged (Day/Boarding) missionary Secondary schools from two different Education Districts in Lagos State but of the same curriculum.

Three research instruments developed by the researcher were used in this study. These are (1) a developed Flipped Classroom Package; (2) Performance test in Mathematics; and (3) Lesson Plan/Note (LN). All these instruments were subjected to both face and content validity by experts. The instruments were also checked for reliability, the inter-rater reliability coefficient of a developed FC package was observed to be 0.79 ; lesson note, 0.83; and test instrument was 0.85 . The developed flipped classroom package was used in the experimental group classroom. Figure 3 and 4 show the screenshot of the flipped classroom package used while the control group participants were subjected to the conventional method of teaching using lesson note only. Both are of the same learning contents. 

Exâfiple: Construct a quadratic
equation in $\mathrm{x}$ whose roots are:
$x-\left(-\frac{3}{2}\right)=0$ and $x-(+7)=0$
$-\frac{3}{2}$ and 7
$x+\frac{3}{2}=0$ and $x-7 \mid=0$
Solution:
There are two Methods...
$\left(x+-\frac{3}{2}\right)(x-7)=0$
Method 1:
Expanding:
The roots are $-\frac{3}{2}$ and 7
This means that, $\mathrm{x}=-\frac{3}{2}$ and $x=7$
$x^{2}-7 x+\frac{3}{2} x-\frac{21}{2}=0$
Multiply through by 2
Subtract each roots from $\mathrm{x}$ and
$2 x^{2}-14 x+3 x-21=0$
$\therefore$ the equation is
equate to zero in turn
$2 x^{2}-14 x+3 x-21=0$

Figure 3: Flipped classroom video clip screenshot on "construct of quadratic"

Example: Find the term that must be added to $x^{2}-22 x$ to make it a perfect square?

Solution:

Let $m^{2}$ represent the value

Then $x^{2}-22 x+m^{2}=(x+m)^{2}$ $x^{2}-22 x+m^{2}=(x+m)(x+m)$

$x^{2}[-22 x)+m^{2}=x^{2}+2 x m+m^{2}$
Equate the middle expressions

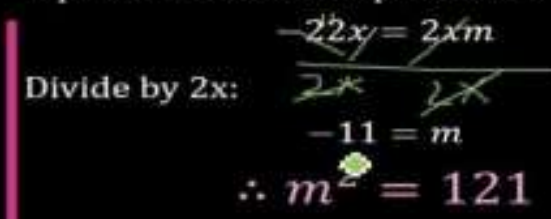

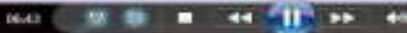

Figure 4: Flipped classroom video clip screenshot on "perfect square"

At the end of the six week-experiment, the researcher and two research assistants administered the test instrument on both the experimental and control groups simultaneously. Analysis of Covariance (ANCOVA) statistics was applied to test hypotheses 1 and 2 on treatment, 3 and 4 on gender at 0.05 significance level using IBM statistical package for social sciences (SPSS) 
version 20.0 to do all statistical analysis. The application of ANCOVA takes care of the differences between groups before treatment (pre-test). Bonferroni pairwise comparison test was conducted to locate the direction of the difference established by ANCOVA.

\section{Results on Hypotheses}

The hypotheses raised were tested and analyzed as follows.

\section{Hypothesis One}

$\mathrm{H}_{\mathrm{O}_{1}}$ : Significant difference does not exist between the post-test performance of students taught mathematics with a Developed Flipped Classroom (FC) package and those taught with Conventional Classroom (CC). in SSS in Lagos, Nigeria.

Table 1 and 2 illustrate the analyses of null hypothesis 1.

Table 1: Descriptive Statistics' on the Post-test Scores for the Experimental and Control Groups

\begin{tabular}{lccc}
\hline Group & $\mathrm{N}$ & Mean & Std. Deviation \\
\hline Flipped Classroom & 147 & 30.234 & 4.7949 \\
Convectional Class & 128 & 25.268 & 5.9821 \\
Total & 275 & 27.751 & 5.3885 \\
\hline
\end{tabular}

Table 2: ANCOVA Result on the Post-test Performance of the Experimental and Control Groups

\begin{tabular}{lcrrrr}
\hline Source & Type III Sum of Squares & df & Mean Square & F & Sig. \\
\hline Corrected Model & $4375.552^{\mathrm{a}}$ & 2 & 2187.776 & 124.738 & .000 \\
Intercept & 16571.314 & 1 & 16571.314 & 960.364 & .000 \\
Pre-test & 2892.680 & 1 & 2892.680 & 166.157 & .000 \\
Group & 2482.158 & 1 & 2482.158 & 146.232 & .000 \\
Error & 4613.478 & 273 & 17.408 & & \\
Total & 194976.000 & 275 & & & \\
Corrected Total & 8887.030 & 274 & & & \\
\hline
\end{tabular}

a. R Squared $=.461$ (Adjusted R Squared $=.48^{\prime}$

Table 1 above shows that the flipped classroom had higher post mean score $(\mathrm{M}=30.23, \mathrm{SD}=$ 
4.80) than their conventional classroom (control group) counterparts $(\mathrm{M}=25.27, \mathrm{SD}=5.98)$, using a benchmark of 20.00. Results in Table 2 for ANCOVA, F $(1,275)=146.232$, p=.00. Since, the $\mathrm{p}$-value $<\alpha$-value of 0.05 , then, the null hypothesis is rejected; this indicates that a significant difference exists between the performance of students taught mathematics using the flipped classroom and those taught using the conventional method as indicated in the mean and standard deviation. The flipped classroom is more effective than the conventional class system in teaching mathematics to students.

\section{Hypothesis Two}

Ho2: There is no significant difference between the retention performance of students taught using a developed FC package and those taught mathematics using the $\mathrm{CC}$ in SSS in Lagos, Nigeria.

Analysis of null hypothesis two is as illustrated in the descriptive statistics Table 3 and the ANCOVA Table 4.

Table 3: Descriptive Statistics on the Retention scores of the Group.

\begin{tabular}{lrcc}
\hline Group & $\mathrm{N}$ & Mean & Std. Deviation \\
\hline Flipped Classroom & 147 & 25.476 & 5.0237 \\
Convectional Class & 128 & 20.756 & 5.3704 \\
Total & 268 & 23.310 & 5.6870 \\
\hline
\end{tabular}

Table 4: ANCOVA Result on the Retention performance of the Experimental and Control Groups.

\begin{tabular}{|c|c|c|c|c|c|}
\hline Source & $\begin{array}{l}\text { Type III Sum of } \\
\text { Squares }\end{array}$ & df & Mean Square & $\mathrm{F}$ & Sig. \\
\hline Corrected Model & $3693.474^{\mathrm{a}}$ & 2 & 1846.737 & 99.029 & .000 \\
\hline Intercept & 12881.735 & 1 & 12881.735 & 690.770 & .000 \\
\hline Pre-test & 2211.028 & 1 & 2211.028 & 118.564 & .000 \\
\hline Group & 2428.767 & 1 & 2428.767 & 130.240 & .000 \\
\hline Error & 4941.820 & 273 & 19.648 & & \\
\hline Total & 154251.000 & 275 & & & \\
\hline Corrected Total & 8635.295 & 274 & & & \\
\hline
\end{tabular}

a. $\mathrm{R}$ Squared $=.428$ (Adjusted $\mathrm{R}$ Squared $=.423$ ) 
As illustrated in Table 3 the FC group had the higher mean score $(\mathrm{M}=25.48, \mathrm{SD}=5.0237)$, while the $\mathrm{CC}$ group had $(\mathrm{M}=20.76, \mathrm{SD}=5.3704)$ using 20.00 as a benchmark. The ANCOVA results shown in Table 4 unveils that there was a significant difference; $F(1,275)=130.240, \mathrm{p}=0.000$. Since the p-value < alpha value of 0.05 , the null hypothesis is rejected, this indicates that a significant difference does exist between the retention performance of students taught mathematics using FC method and CC method as indicated in the mean and standard deviation.

\section{Hypothesis Three}

$\mathrm{H}_{\mathrm{O}_{3}}$ : Significant difference does not exist between the post-test performance of male and female students taught mathematics using the FC in SSS in Lagos, Nigeria.

The analysis of the post-test performance of students based on gender is as illustrated in Table 5 for descriptive statistics and Table 6 on the ANCOVA results for the sexes.

Table 5: Descriptive Statistics for Post-test Scores of Male and Female Students in FC Group.

\begin{tabular}{cccc}
\hline Gender & N & Mean & Std. Deviation \\
\hline Male & 78 & 28.45 & 4.980 \\
Female & 69 & 28.42 & 4.662 \\
Total & 147 & 28.44 & 4.821 \\
\hline
\end{tabular}

Table 6: ANCOVA on the Post-test Scores of Male and Female Students in FC Group

\begin{tabular}{cccccc}
\hline Source & Type III Sum of Squares & df & Mean Square & F & Sig. \\
\hline Corrected Model & $687.630^{\mathrm{a}}$ & 2 & 343.815 & 17.962 & .000 \\
Intercept & 18017.406 & 1 & 18017.406 & 898.023 & .000 \\
Pre-test & 687.621 & 1 & 687.621 & 35.923 & .000 \\
Sex & 4.317 & 1 & 4.317 & .225 & .636 \\
Error & 2718.122 & 145 & 19.132 & & \\
Total & 120698.000 & 147 & & & \\
Corrected Total & 3405.752 & 146 & & & \\
\hline
\end{tabular}

a. R Squared $=.202($ Adjusted R Squared $=.191)$

Results in Table 5 indicates that the male students in the flipped classroom had higher mean score $(\mathrm{M}=28.45, \mathrm{SD}=4.98)$ than their female counterparts $(\mathrm{M}=28.42, \mathrm{SD}=4.66)$ using a benchmark of 20.00. However, the higher mean score for the male students did not indicate any significant 
difference in ANCOVA results in Table 6, $\mathrm{F}(1,147)=0.225, \mathrm{p}=0.636$, the $\mathrm{p}$-value $>0.05$ alpha value. Thus, the null hypothesis that no significant difference exists between the post-test performance of male and female students taught mathematics with FC is accepted.

\section{Hypothesis Four}

$\mathrm{H}_{4}$ : Significant difference does not exist between the retention performance of male and female students taught mathematics using the flipped classroom in SSS in Lagos, Nigeria.

The analysis for testing hypothesis two for male and female retention performance in flipped classroom mathematics class are as shown in Table 7 for the descriptive statistics and Table 8 on the ANCOVA results for sexes.

Table 7: Analysis of Retention performance of Male and Female Students in Mathematics in FC.

\begin{tabular}{lrcc}
\hline Gender & $\mathrm{N}$ & Mean & Std. Deviation \\
\hline Male & 78 & 25.36 & 5.329 \\
Female & 69 & 26.73 & 5.673 \\
Total & 147 & 26.05 & 5.501 \\
\hline
\end{tabular}

Table 8: ANCOVA on the Retention Test Scores of Male and Female Students in FC Group

\begin{tabular}{lrrrrr}
\hline Source & \multicolumn{1}{c}{ Type III } & & & & \\
Corrected Model & Sum of Squares & df & Mean Square & \multicolumn{1}{c}{ F } & Sig. \\
Intercept & $487.810^{\mathrm{a}}$ & 2 & 243.905 & 11.008 & .000 \\
Pre-test & 14010.492 & 1 & 14010.492 & 642.316 & .000 \\
Sex & 479.680 & 1 & 479.680 & 22.649 & .000 \\
Error & 1.414 & 1 & 1.414 & .056 & .721 \\
Total & 3146.356 & 145 & 22.157 & & \\
Corrected Total & 97742.000 & 147 & & & \\
\hline
\end{tabular}

Results in Table 7 indicate that the female students in the flipped classroom had higher mean score $(M=26.73, S D=5.673)$ than their male counterparts $(M=25.36, S D=5.3290$ with a benchmark of 20.00. However, the higher mean score for the female students reveals a significant difference in ANCOVA results in Table $8, \mathrm{~F}(1,147)=0.056, \mathrm{p}=0.721$. The $\mathrm{p}$-value is higher than the $\alpha$ - 
value of 0.05 ; hence, the null hypothesis is not rejected. This implies that there was no significant difference between the retention test performance of male and female students who were taught mathematics with a flipped classroom approach in SSS in Lagos, Nigeria ${ }_{2}$ as indicated in the mean and standard deviation.

\section{Discussions on Research Findings}

The main purpose of the research was to determine the adequacy and utilization of the flipped classroom method on SSS students' performance in Mathematics in Lagos, Nigeria based on the developed model (FC package). Findings in Table 1 show that the post-test performance of SSS students who were taught mathematics with the flipped classroom approach and those taught with the conventional method had the least mean. This shows that students in the flipped classroom setting performed significantly better than those in the conventional classroom. The increase in students' involvement in classroom activities and learning would have accounted for the better performance of students. Also, the results in Table 2 unveil that the post-test score was significantly higher for the flipped classroom group than the conventional classroom counterpart. These findings indicate that the flipped classroom approach is effective in enhancing students' performance in SSS in Lagos, Nigeria. This agrees with the findings of Charles-Ogan and Williams (2015); Esperanza, Fabian, and Toto (2016) and (Fulton, 2012) that revealed that the use of flipped classroom model in southern Minnesota school in mathematics class resulted in gains in student achievement and engagement.

Furthermore, Table 3 shows a significant difference between the retention test performance of students taught Mathematics using a developed flipped classroom package and those taught using conventional classroom method in SSS in Lagos, Nigeria. The significant difference was in favour of the flipped classroom as reflected in Table 4. This is in agreement with Marcellious (2001); Chianson (2008) and Iji (2002) who indicated that retention in Mathematics is not acquired by mere rote learning but through suitable teaching method like the flipped classroom.

Table 5 reveals no significant difference in male and female student's post-test performance when taught mathematics with the flipped classroom method; there was no significant difference between the retention test performance of male and female students who were taught mathematics with flipped classroom approach as shown on Table 6. This contradicts and 
challenges the findings of Frempbong and Ayia (2006) in which female Ghanaian students are less successful in learning Mathematics due, reportedly, to their low interest, lack of confidence, and low academic expectation. The findings agree rather with Abiam and Odok (2006) who found no significant relationship between gender and achievement in number and numeration, and algebraic process and statistics for their research subject in Nigeria. This implies that the flipped classroom approach to teaching and learning of mathematics is learner friendly, has no gender bias, and is flexible.

The findings from Table 7 do not support Amatobi and Amatobi (2013)'s position that the achievement of students in Mathematics at the high school level in Amurie-Omanze in Imo State, South Eastern Nigeria has been reported poor. This may be due to the "bridge" nature of the sample population chosen for this study and the advantage that Lagos has as a desirable urban city for good teachers. The findings of this study as reveals on Table 8 are consistent with those of Bergman and Sams (2013) and Alverze (2012), and Jacob and Mathew (2103) that male and female students can perform equally well provided they learn under the same academic condition. Hence, the flipped classroom teaching method does not show any gender bias.

\section{Conclusion}

Effective teaching and learning cannot be established without a proper learning process. The need to continue to re-orientate Nigerian classrooms from teacher-centredness to studentcentredness to enhance students' engagement and boost students' learning is well recognised. This study provides evidence that the flipped classroom makes teaching and learning enjoyable, effective, and satisfying. This research has established the instructional values of the flipped classroom method of teaching. Findings on gender were unique and instructive. The hypotheses on gender revealed that gender did not influence both the retention and academic performance of students when they were taught mathematics with the flipped classroom in SSS in Lagos, Nigeria. Students tend to perform better in post-test than retention test period. This result may indicate that although flipped classroom enhanced post-test performance, the effect had receded before the retention test in SSS in Lagos, Nigeria.

\section{Recommendations}

Based on the findings of this research, the following recommendations are made to redress the problems of mathematics learning in secondary schools in Lagos, Nigeria: 
1. Educators should master and adopt the flipped classroom approach because it is a studentcentred learning strategy that actively engages the students;

2. Adequate ICT facilities should be provided in schools for easy access to boost the application of flipped classroom in schools

3. Teachers should be provided with continuous training via seminars, workshops and conferences on the utilization of innovative learning strategies like the flipped classroom. This will enable them to use this approach with expertise.

4. All stakeholders in the education industry should appreciate, support and sustain the use of the flipped classroom in SSS in Lagos and Nigeria as a whole.

\section{References}

Abiam, P. O., \& Odok, J. K. (2006). Factors in Students' achievement in different branches of secondary school Mathematics. Journal of Education and Technology, 1, 161-168.

Alverze, B. (2012). Flipping the Classroom: Homework in Class, Lessons at Home. Education Digest: Essential Readings Condensed for Quick Review, 77(8), 18-21.

Amatobi, V. E., \& Amatobi, D. A. (2013). The influences of gender and attitude differences on students' achievement in mathematics in Nigerian secondary schools: a case study of comprehensive secondary school Amurie-Omanze in South-Eastern Nigeria. American Journal of Research Communication: www.usa-journals.com, ISSN: 2325-4076.

Amelink, C. T. (2009). Literature overview: Gender differences in mathematics performance. Retrieved from http/www.AWEonline.org on 20/05/2011.

Bergmann, J., \& Sams, A. (2012). Flip Your Classroom: Reach Every Student in Every Class Every Day. International Society for Technology in Education; 1st Edition (June 21, 2012), 112. ISBN 1564843157,9781564843159

Sams, A., \& Bergmann, J. (2013). Flip your students' learning. Educational Leadership, 7, 1620. https://www.scirp.org/(S(351jmbntvnsjt1aadkposzje))/reference/ReferencesPapers.aspx? $\underline{\text { ReferenceID }=882870}$ 
Bull, G., Ferster, B., \& Kjellstrom, W. (2012). Inventing the flipped classroom. Learning \& Leading with Technology, 40(1), 10-11. Retrieved from https://www.learningandleadingdigital.com/learning leading/201208?pg=12\#pg12

Charles-Ogan, G., \& Williams, C. (2015). Flipped classroom versus a conventional classroom in the learning of mathematics, University of Port Harcourt, Nigeria. British Journal of Education, 3 (6), 71-77. Retrieved on October 5, 2016, from www.eajournals.org.

Chianson, M. M. (2008). Effect of cooperative learning on students' achievement and retention in circle geometry in secondary schools in Benue State. Unpublished M.Ed. Thesis Benue State University, Makurdi.

Fabian, K., Esperanza, P., \& Toto, C. (2016). Flipped Classroom Model: Effects on Performance, Attitudes and Perceptions in High School Algebra. In K. Verbert, M. Sharples, \& T. Klobucar (Eds.), Adaptive and Adaptable Learning: Lecture Notes in Computer Science, 9891, 85-97. Springer-Verlag. https://doi.org/10.1007/978-3-31945153-4_7

Estes, M. D., Ingram, R., \& Liu, J. C. (2014). A review of flipped classroom research, practice, and technologies. International HETL Review, 4(7), [online]. Retrieved from: https://www.hetl.org/feature-articles/a-review-of-flipped-classroom-research-practiceand-technologies

Federal Republic of Nigeria (FRN, 2014). National Policy on Education. Yaba: Revised Edition NERDC Press.

Fulton, K. (2012). Upside down and inside out: Flip your classroom to improve student learning. Learning \& Leading with Technology, 39(8), 12-17.

Iji, C. O. (2002). Effects of Logo and basic programmes on achievement and retention in the geometry of junior secondary school students. Unpublished PhD Thesis. University of Nigeria, Nsukka.

Jacob, L. B. \& Mathew, A. V. (2013). The flipped classroom: A survey of the research. In Proceedings, Annual Conference \& Exposition. Paper ID \# 6219: 1-18. 
Impact of Flipped Classroom on Mathematics Learning Outcome of Senior Secondary School Students in Lagos, Nigeria

Makinde, S. O. (2017). Effects of A Developed Flipped Classroom Package on Senior Secondary School Students' Performance in Mathematics in Lagos, Nigeria. Unpublished PhD Thesis, University of Ilorin, Ilorin, Nigeria. 86-90.

Makinde, S. O. (2020). Influence of Social/Mass Media as a Change Agent on Childhood Social Pedagogy and Achievement. Indonesian Journal of Early Childhood Education Studies, 9(1), 1-7. http://dx.doi.org/10.15294/ijeces.v9i1.36259

Marcellious, G. (2001). What factors affect retention in the classroom? Wakefield High School, Arlington County (VA) Public Schools. Kenyatta University School of Economics (KU) Course Hero, 1-7. Retrieved on November, 27, 2019 from https://gse.gmu.edu/assets/docs/lmtip/vol3/M.Gaines.doc

Nwosisi, C., Ferreira, A., Rosenberg, W. \& Walsh, K. (2016). A study of the flipped classroom and its effectiveness in flipping thirty percent of the course content. International Journal of Information and Educational Technology, 6(5), 348-351. DOI:

10.7763/IJIET.2016.V6.712

Okebukola, P. (2015). Students get e-learning platform to boost academic performance. $12^{\text {th }}$ January 2015. Vanguard newspaper. In Education. Retrieved on June 2, 2020, from https://www.vanguardngr.com/2015/01/students-get-e-learning-platform-boost-academicperformance/

Olunloye, O. (2010). Mass Failure in Mathematics: A National Disaster. Nigerian Tribune, $7^{\text {th }}$ February, 2010. Retrieved on 08/05/2011 from http://www.tribune.com.nig

Parson, S., Croft, A., \& Harrison, M. (2009). Does students' confidence in their ability in mathematics matters? Teaching Mathematics and its Applications: An International Journal of the IMA, 28(2), 53-68, https://doi.org/10.1093/teamat/hrp010 Retrieved on May 2, 2017, from https://academic.oup.com/teamat/articleabstract/28/2/53/1662162?redirectedFrom=fulltext

Strayer, J. F. (2007). The effects of the classroom flip on the learning environment: A comparison of learning activity in a traditional classroom and a flip classroom that used an intelligent tutoring system. Unpublished doctoral dissertation, The Ohio State University, America. 
Toppo, G. (2011). 'Flipped' classrooms take advantage of technology. In USA Today 10/6/11, Education Next: A journal of opinion and research, 11(3). Retrieved on November 12, 2014, from https://www.educationnext.org/behind-the-headline-flipped-classrooms-takeadvantage-of-technology/

Tucker, B. (2012). The flipped classroom: Online instruction at home frees class time for learning. Education Next: A journal of opinion and research, 12(1). Retrieved on November 12, 2014, from http://educationnext.org/the-flipped-

classroom/\#une.edu/pqdweb?did=2530882881\&sid=11Fmt=3\&clientid=8421\&RQT=30 $\underline{9 \& \mathrm{VName}=\mathrm{PQD}}$

U.S. Department of Education. (2004). National education technology plan. http://www.nationaledtechplan.org/ (Retrieved September 28, 2019).

West African Examinations Council, WAEC. (2019). Chief examiner's Report on students' performance Statistics for 2014, 2015, 2016, 2017, 2018 \& 2019.

Yusuf, M. O. (2006). Using the Internet for Teaching, Learning and Research in Tertiary Institutions. The Journal of Nigerian Association of Teachers of Technology, JONNAT, $6(1), 163-171$. 